\title{
Pemberdayaan Kelompok Tani Lokakarya Dalam Pemanfaatan Kain Perca Desa Lembah Sari Kecamatan Rumbai Pesisir
}

\author{
RITA WIYATI $^{1}$; SRI MARYANTI ${ }^{2}$; M.THAMRIN ${ }^{3}$ \\ ${ }^{1,2,3}$ Universitas Lancang Kuning \\ Jln. Yos Sudarso KM 08 Rumbai Telp. (0761) 52581 \\ E-mail : ritawiyati@unilak.ac.id
}

\begin{abstract}
Lembah Sari Village, Rumbai Pesisir Subdistrict, there are a number of farmer groups from one of the Workshop farmer groups, some of the farmer groups available are inactive. During the survey meeting with the chairman of GAPOKTAN, he stated that his members wanted to be re-empowered in other words, the Workshop group was reactivated in the activities of its farmer groups. Most of the members are pure housewives who only take care of the family, without any desire and willingness to seek additional hope. Based on this, our community service team from the faculty of economics gathered provided the skills and empowered the mothers of the LokaKarya farmer group in Lembah Sari village in their skills in making women's accessories. The purpose of this Community Service is to produce products in the form of bross, necklaces or bracelets for women's accessories that can help increase family money and to motivate mothers of members of the Lembah Sari village farmer group to become entrepreneurs by producing their products. The specific target that wants to succeed is so that the members of the farmer group are more creative and innovative to have a business with cheap capital. The method used to achieve the intended purpose is to conduct counseling about the interests of entrepreneurship and training in making bross hijab and also not using large capital considering the members of the farmer group workshops have less established investments. The methods of implementing the program that will be carried out are: understanding in entrepreneurship, training in making headscarf accessories, assistance in making headscarf accessories. All of these methods are an integral part of this IbM program. The results and results obtained in this PKM, when the pretest of the majority of PKM participants were still wrong, the participants were less likely to postpone the pretest, because some members of the farmer group had received training, some were active in the village PKK, and thus increased the number of participants who did not need the spirit of the members present. And in the simulation the participants quickly understood it and were creative. The essence of this service requires motivating members of the farmer group to be able to be enthusiastic about entrepreneurship, no matter how small the effort that we do, still must be with perseverance and sincerity.
\end{abstract}

Keywords: Entrepreneurship, Creative

Di Desa Lembah sari, terdapat beberapa kelompok tani, salah satunya kelompok tani Lokakarya, dimana sudah beberapa tahun yang silam kelompok tani tersebut tidak aktif atau fakum, dikarenakan ada permasalahan pribadi. Berkenaan dengan hal ini kami menyampaikan inisiatif kepada ketua gabungan kelompok tani desa lembah sari yang diketuai oleh bapak Basuki dan menyampaikan untuk dapat dihidupkan kembali kegiatan kelompok tani tersebut.

Dengan kondisi rata rata kehidupan para ibu ibu tersebut hanya mengurus rumah tangganya saja,kelompok Ibu Ibu ini kegiatan sehari hari dalam bersosial adalah kegiatan wirid dan arisan saja. Diantara kelompok Ibu Ibu tersebut sebagian besar rutinitas yang dijalaninya untuk membantu menopang biaya hidup keluarganya ada yang buruh kerja cuci gosok ditetangga yang membutuhkannya, ada juga yang buka warung harian. Untuk mengisi kekosongan waktu sehari harinya Ketua Gapoktan dan anggotanya merasa membutuhkan motivasi dan pelatihan dalam berwirausaha, yang harapannya Ibu 
ibu anggota kelompok tani Lokakarya didesa Lembah Sari tersebut memiliki kreativitas dan dapat membantu kehidupan keluarga. Dengan memanfaatkan sisa potongan kain jahitan atau kain perca untuk dapat membuat souvenir bros jilbab atao produk jenis lainnya seperti keset atau tas. Disini tim pengabdian akan lebih fokuskan pelatihan dalam membuat assesoris untuk wanita terutama untuk mempercantik jilbabnya yaitu bros jilbab. Dengan memanfaatkan kain perca dapatlah diperoleh peluang usaha bagi ibu ibu kelompok Tani Lokakarya desa Lembah Sari kelurahan Rumbai Pesisir, hal ini dapat juga untuk menambah penghasilan bagi keluarganya setidaknya untuk dipakai sendiri atau keluarganya tanpa harus membeli mengeluarkan uang untuk memakai assesoris dipakaian yang kita kenakan. Disamping itu rata-rata merupakan ibu rumah tangga yang kehidupan ekonomi dinilai masih kurang mapan sehingga kegiatan seperti Pengabdian Kepada Masyarakat ini sangat perlu diadakan.

Keberhasilan sebuah usaha terutama ditentukan oleh keberanian seorang pengusaha dalam membaca situasi dan menciptakan peluang. Kemudian secara cepat mengambil keputusan dengan perhitungan yang cermat. Making money without money, atau menghasilkan uang tanpa modal adalah sebuah ungkapan yang dapat direalisasikan. Keberhasilan seseorang sangat tergantung pada kreativitas masing masing individu (Ciputra, 2008: 19). Ketakutan akan terjadinya kegagalan usaha sebelum memulai usaha itu sendiri merupakan penghambat terbesar bagi seseorang untuk meraih keberhasilan . Keberanian melakukan inovasi secara terus menerus, memacu aktivitas, untuk memperoleh produk produk baru yang unik, inovasi tidak mengikuti trend yang ada, tetapi terus menerus melakukan pengubahan sehingga produk yang dihasilkan selalu berbeda.Usaha yang langgeng biasanya adalah usaha yang dibangun dengan kejujuran yang meliputi seluruh aspek usaha sejak bahan, produksi, hingga pemasarannya.

Dimasa pembangunan sekarang nilai ekonomi semakin berperan, maka kerajinan dipandang sebagai asset yang menguntungkan untuk dikembangkan. Dengan kata lain, kerajinan memiliki potensi ekonomi dalam perdagangan dan dunia pariwisata. Desa Lembah Sari merupakan bagian daerah yang paling dekat dengan kawasan wisata danau buatan yang wilayah tersebut bagian dari destinasi wisata danau, diKota Pekanbaru Propinsi Riau, ada kesempatan dan peluang bagi masyarakat setempat terutama ibu ibunya untuk dapat memanfaatkan peluang usaha dengan menjual produk souvenir hasil olahannya. Oleh karena itu kegiatan pemberian motivasi dan menumbuhkan jiwa berwirausaha diharapkan dapat meningkatan pengetahuan, dapat mngembangkan kreativitas ibu ibu rumah tangga, bakat yang terpendam atau bakat yang belum tersalurkan melalui kegiatan ini serta dapat meningkatkan pendapatan serta kesejahteraan ibu ibu kelompok Tani Lokakarya desa Lembahsari.

Kewirausahaan adalah disiplin ilmu yang mempelajari tentang nilai, kemampuan, dari prilaku seseorang dalam mengahadapi tantangan hidup untuk memperoleh peluang dengan berbagai resiko yang mungkin dihadapinya. (Sudayono; Asep Saefullah; 2011;9).

Semangat kewirausahaan yang perlu dibudayakan antara lain :

1. Kemauan kuat untuk berkarya (utamanya dibidang ekonomi) dengan semangat mandiri

2. Mampu membuat keputusan yang tepat dan berani mengambil resiko

3. Kreatif dan inovatif

4. Tekun, teliti, dan produktif

5. Berkarya dengan semangat kebersamaan dan etika bisnis yang sehat

Berdasarkan kelima semangat kewirausahaan tersebut maka jelas bahwa 
yang dibutuhkan oleh seorang pengusaha atau wirausaha adalah berkarya dengan semangat mandiri yang disertai dengan semangat kebersamaan dan kekeluargaan . Hal ini menunjukkan bahwa wirausaha hanya memikirkan bisnisnya sendiri, melainkan juga dituntut untuk memperhatikan bisnis orang lain. Dengan kata lain, tidak boleh saling menjatuhkan, terutama pada bisnis sejenis. Persaingan harus dilakukan secara sehat agar mendorong munculnya wirausaha wirausaha baru yang tangguh, kreatif, inovatif, produktif namun tetap menjaga karakter bangsa Indonesia yang ramah, bergotong royong persaudaraan sejati, dan tidak melanggar etika bisnis. Manfaat kewirausahaan ditunjukkan bahwa pemilik bisnis kecil menyakini bahwa mereka bekerja lebih keras, menghasilkan lebih banyak uang, dan merasa lebih bahagia daripada bekerja untuk orang lain atau perusahaan lain.

Dalam situasi ekonomi sesulit apapun, wirausaha harus tetap optimis dalam menggeluti bisnisnya. Sebab keberanian wirausaha dalam menggeluti bisnisnya terletak pada optimisme. Dengan tetap optimis maka kita akan terus termotivasi dan cemerlang dalam memanfaatkan peluang bisnis.

Seseorang yang telah memutuskan untuk menjadi pelaku usaha meskipun dalam skala kecil dapat disebut sebagai wirausahawan. Sebagai seorang pelaku usaha atau wirausahawan maka ia perlu mengembangkan jiwa kewirausahaaan. Dalam praktek sering kita menyaksikan seorang wirausahawan terjadi dengan sendirinya dan kemudian sukses. Untuk yang demikian ini kita sebut mereka memilki bakat. Namun kita juga sering menyaksikan, seseorang yang beberapa tahun yang lalu ikut membantu orang lain berjualan nasi dan sukses. Kasus sebagaimana yang terakhir ini bisa kita sebut sebagai ketrampilan yang dibentuk dari kebiasaan , alah biasa karena terbiasa kata pepatah. (Mulyadi Nitisusastro; 2009;26).
Dalam pengabdian masyarakat yang akan kami lakukan ini kami peruntukkan untuk ibu ibu anggota kelompok Tani Lokakarya desa Lembahsari yang hampir sebagian besar profesinya hanya ibu rumah tangga saja. Maka menururt Tim kami begitu penting kegiatan Pengabdian Kepada Masyarakat ini dilakukan didaerah tersebut dan dapat memberikan manfaat bagi diri sendiri serta dalam kegiatan ini dapat meningkatkan perekonomian keluarga, hal ini disebabkan tingkat pendidikan dari mitra yang rata-rata SMP dan SMA sehingga mempengaruhi kreatifitas mereka.

\section{METODE}

Metode pelaksanaan dilakukan dengan ceramah, terkait pemahaman tentang kewirausahaan, motivasi untuk berwirausaha, pemanfaatan barang bekas. Diskusi atau dialog dengan peserta pengabdian kepada masyarakat. Memberikan pertanyaan (quisioner) kepada peserta sebelum dan setelah mendapatkan materi dari Tim Pengabdian Masyarakat. Simulasi (praktek pembuatan kerajinan tangan sisa potongan kain jahitan atau bisa juga dinamakan kain perca) sebagai assesoris wanita berupa bross jilbab.

\section{HASIL}

Pelaksanaan kegiatan pengabdian kepada masyarakat yang dilakukan oleh tim fakultas Ekonomi Unilak adalah kegiatan untuk memberikan motivasi kepada para ibu ibu rumah tangga yang tergabung dalam kelompok tani Lokakarya. Kelompok tani lokakarya sudah beberapa tahun belakangan ini tidak berperan aktif, pada saat inilah momment yang tepat untuk menggugah kembali semangat anggota kelompok tani tersebut yang semuanya ibu ibu, yang sebagian besar para ibu ibu tersebut saat pekerjaannnya fokus mengurus rumah tangga saja. Pada kelompok tani daerah desa lembah sari kami sebagai tim pengabdian dari fakultas ekonomi sudah pernah melakukan pengabdian didesa 
tersebut dengan kelompok tani yang lain yaitu kelompok tani Sari Buah dan Ladang Sari, anggota kelompok tani tersebut juga semuanya ibu ibu. Pada tahapan pengabdian masyarakat yang kali ini kami sebelum melakukan pemahaman tentang kiat kiat berwirausaha, kami berikan terlebih dahulu Pre test, tujuannya untuk mengetahui sejauh mana pemahaman peserta terhadap pemahamanan tentang kewirausahaan. Dari prestest yang dilakukan, masih ada peserta PKM yang menjawab salah.

Pada pelaksanaan pengabdian turun lapangan kedua yang kami lakukan memberikan motivasi dan pemahaman terhadap kewirausahaan bagi ibu ibu kelompok tani Lokakarya, yang kami tekankan disini bahwasannya untuk memulai suatu usaha, apapaun itu usahanya kita tidak boleh takut untuk memulainya, meskipun usaha itu masih pemula. Minat ibu ibu kelompok tani Lokakarya untuk berwirausaha cukup antusias karena sebelum kami melakukan pengabdian masyarakat ada beberapa ibu ibu terutama yang masih muda pro aktif untuk menayakan kepada Tim tentang berwirausaha, seperti membuat asesoris jilbab dari bahan manik manik, dan para ibu ibu kelompok tani Lokakarya tersebut sangat tertarik. Untuk tahap terakir, kami tim pengabdian masyarakat memberikan contoh atau simulasi memperagakan bagaimana memanfaatkan bahan dari sisa potongan jahitan dapat bermanfaat menjadi assesoris jilbab atau dapat sebagai souvenir.

Dalam hal ini ibu ibu kelompok tani Lokakarya dapat mempraktekannya dengan bahan yang sudah kami sediakan. Dari peragaan atau simulasi, bermacam bentuk dan model dapat dibuat baik untuk assesoris jilbab maupun souvenir untuk pernikahan. Justru pada tahap turun lapangan yang kedua ini pada saat mempraktekkan membuat souvenir, ibu ibu kelompok tani tersebut lebih berminat dengan mempraktekan yang menggunakan akrilik dari pada dengan potongan kain perca, disini tim pengabdian juga mengajarkan hal tersebut. Pada tahapan mempraktekkan dengan merangkai bahan akrilik , kami tim pengabdian tidak hanya mempraktekkan membuat bros saja tetapi juga mencoba merangkai untuk assesoris kalung dan gelang. Ibu ibu kelompok tani Lokakarya sangat senang dengan diberikannya pelatihan praktek tersebut, karena ibu ibu kelompok tani tersebut juga merasakan dapat manfaatnya sekaligus dapat barang dari hasil yang dipraktekkannya untuk dibawa pulang, yang nantinya masing amsing ibu ibu tersebut dapat mengkreasikannya maupun memodifikasikan dirumahnya masing masing, setelah mendapatkan dari pelatihan ini.

Dari hasil pre test dan post test inilah kami tim pengabdian dapat memberikan penilaian atau dapat membandingkan , apakah kegiatan pengabdian kami ini berhasil atau tidak dari sebelum kita berikan pemahaman serta peragaan atau praktek dan setelah mendapatkan pemahaman, peragaan atau simulasi. Dalam kegiatan pengabdian ini peserta didominasi ibu ibu yang umurnya masih produktif, meskipun ibu ibu yang umurnya sudah lanjut usianya juga ikut berlatih dan mendengarkan arahan dari tim pengabdian kami.

\section{PEMBAHASAN}

Luaran yang dicapai dalam kegiatan pengabdian ini adalah berupa produk yang dihasilkan yaitu produk Bros Jilbab sebagai assesoris wanita, Gelang dari akrilik, kalung dari akrilik, bando untuk anak anak.

Berdasarkan hasil pengabdian ini dapat disimpulkan bahwa pemahaman secara teori tentang kewirausahaannya masih sangat terbatas, sebelum pengabdian masyarakat ini dilaksanaan. Dengan berlatar belakang pekerjaan utamanya ibu rumah tangga. Hal ini sudah dibuktikan bahwa semua peserta lebih cepat dapat memahaminya pada waktu diadakan simulasi atau praktek membuat assesoris bros, dan kebetulan sebagian anggota kelompok tani tersebut juga sudah mendapatkan pelatihan tersebut yang diselenggarakan oleh kelurahan. Sebagian 
besar peserta pengabdian masyarakat mampu membuat assesoris dari kain perca dan kreatif.

Dari pengamatan selama turun kelokasi pengabdian, kami dari tim pengabdian berharap peserta dengan segera dapat menjalankan usahanya meskipun berawal dari modal yag sangat kecil, karena disini yang sangat dibutuhkan kreativitas yang dihasilkan berupa produk assesoris jilbab, harapan kami peserta tertarik dan minat dengan berwirausaha, sekecil apapun itu jenis usahanya.

Kami berharap bahwa ibu ibu kelompok tani Lokakarya desa Lembah Sari sebagai pesertanya, setelah kami berikan materi secara teoritis dan praktek memperagaan bagaimana cara membuat atau memanfaatkan sisa sisa potongan kain jahitan serta merangkai bahan dari akrilik,diharapkan ibu ibu anggota kelompok tani Lokakarya dapat mengembangkan kreativitasnya dilingkungan rumah tinggalnya.

\section{SIMPULAN}

Kesimpulan yang dicapai dalam PKM ini, saat pretest sebagian jawaban peserta PKM masih ada yang salah, peserta postest lebih sedikit daripada saat pretest, karena sebagian anggota kelompok tani sudah mendapat pelatihan, sebagian aktif diPKK kelurahan, tetapi dengan berkurangnya jumlah peserta tidak mengurangi semangat anggota yang hadir. Dan dalam simulasipun peserta cepat memahaminya dan kreatif. Inti dari pengabdian ini mengajak memotivasi anggota kelompok tani untuk dapat semangat dalam berwirausaha, sekecil apapun usaha yang kita lakukan,tetap harus dengan ketekunan dan kesungguhan hati.

\section{DAFTAR RUJUKAN}

Abdullah Abiding, SE, 2013 ,Jurnal Koperasi dan UMKM, Universitas Hasanuddin, www.bimakab.go.id

Asep Saefullah, 2011, Kewirausahaan, Penerbit andi Yogyakarta

Ciputra, Harian Kompas, Penerbit Gramedia

H. Masngudi, 2000, buku ajar Kewirausahaan, Fakultas Ekonomi Universitas Borobudur, Jakarta

Kasmir, 2006, kewirausahaan, Penerbit PT. Raja Grafindo Persada Jakarta

Mulyadi Nitisusastro, 2009, Kewirausahaan \&Manajemen Usaha Kecil, penerbit Alfabeta Bandung Martin Perry, 2002, Mengembangkan usaha kecil, penerbit PT. Rajagrafindo Persada, Jakarta

Supardi, 1999, Tantangan dan Peluang bisnis Usaha Kecil dan Menengah, penerbit UII Press Yogyakarta

Rita Wiyati dan Tim, PKM Usaha Menumbuhkan Jiwa Kewirausahaan Bagi Mahasiswa STIKes Al Insyirah Pekanbaru, Tahun 2016 